\title{
'MAKING OUR LAW STUDENTS COMPREHEND FOREIGN LEGAL TERMINOLOGY: THE QUEST FOR IDENTIFYING FUNCTION, CONTEXT, THE SEMAINON AND THE SEMAINOMENON IN THE TEACHING OF COMPARATIVE LAW'
}

\author{
Antonios Emmanuel PLATSAS ${ }^{15}$ \\ LLB, LLM, PhD, PGCert, FHEA \\ University of Derby \\ School of Law \& Criminology, Faculty of Business, Computing and Law, Kedleston \\ Road, University of Derby, Kedleston Road, DE22 1GB, UK
}

A.Platsas@derby.ac.uk

,In my own teaching of comparative law I have often felt that, like Bagehot's monarch, I had a duty to warn and a duty to encourage. To teach students not to be lured by homonyms and not to be afraid of synonyms'. (Kahn-Freund 1965, 19)

\begin{abstract}
This paper will explore the implications in relation to the possibility of making law students comprehend foreign legal terminology. The starting point of our analysis, our hypothesis, will be that the law student is not necessarily equipped with foreign language skills. For this reason the author will attempt to demonstrate that comparative lawyers must familiarise their unfamiliarised (students of law) with familiar domestic ${ }^{16}$ terminology where this is possible. If no such familiar concepts can be found, the comparative lawyer should attempt to proceed with 'translating' foreign legal concepts by the use of 'close (functional) terminological equivalents' in one's domestic legal language (school of functionalism). If, on the other hand, no parallel legal devices for the foreign legal term are found in one's domestic jurisdiction, the comparative lawyer should proceed by deploying a contextual approach in his analysis/teaching (school of contextualism). Above all, one is reminded that words are mere conventions. So too legal terms are mere conventions. As a result, it would be neglectful to not state that our students must be assisted

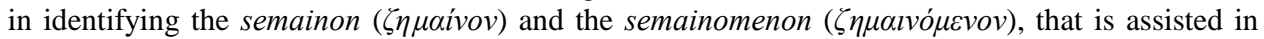
identifying the signified and the signifier, when they engage themselves with foreign legal terminology in their comparative law studies. Additionally, as Van Hoecke has argued, apparently disconnected notions, concepts or areas of law may well be relevant to each other (Van Hoecke $2004,175)$. Yet, it would be perfectly 'legitimate' on certain occasions for one to compare prima facie connected terms such as 'Interprétation - Interpretation or Construction - Auslegung' respectively in French, English and German, since these terms are a perfectly valid comparative trio (all words basically refer to the same intellectual activity) (Platsas 2008, 6; quoting Van Hoecke,
\end{abstract}

${ }^{15}$ Lecturer in Comparative Law (Derby). The author wishes to thank another colleague of his, David Hodgkinson, for proofreading the work. The work has been conducted under the Teaching Informed by Research (TIR) Initiative of the University of Derby. The usual disclaimer in relation to personal omissions and errors applies.

${ }^{16} \mathrm{Cf}$. Zweigert and Kötz 1998, 35; according to them the comparatist can only reach ideal results, if he 'eradicates the preconceptions of his native legal system.' 


\section{Comparative Legilinguistics vol. 2/2010}

op. cit., n. 3). All in all, the paper will conclude that the comparative lawyer should be constantly reminded of the difficulties that his/her students might have when dealing with foreign legal terminology, because of one has it that even experienced comparative lawyers can face problems of comprehension when dealing with foreign legal terminology.

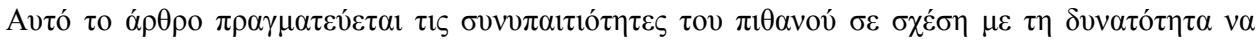

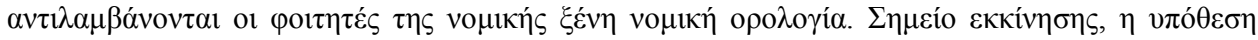

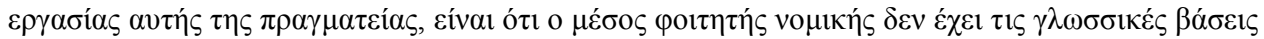

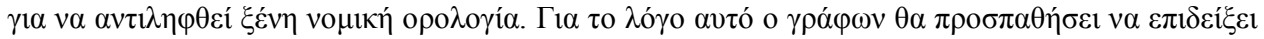

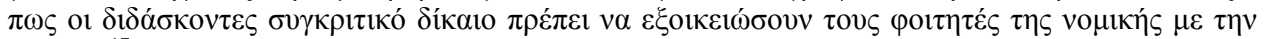

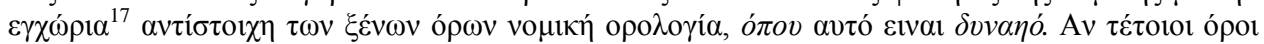

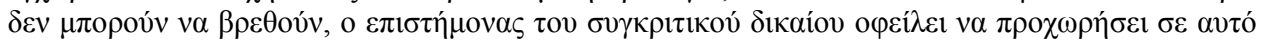

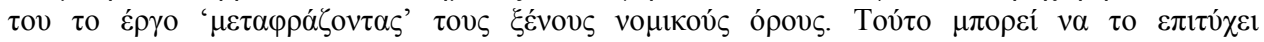

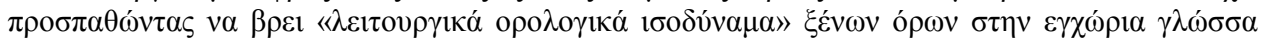
( $\lambda \varepsilon 1 \tau o v \rho \gamma 1 \sigma \mu o ́ \varsigma)$. А

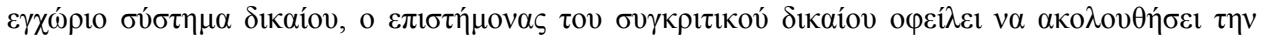

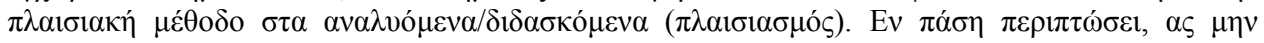

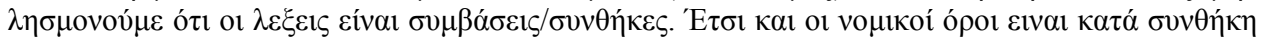

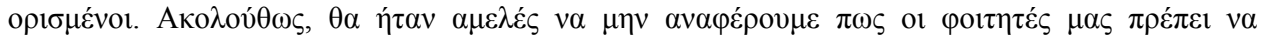

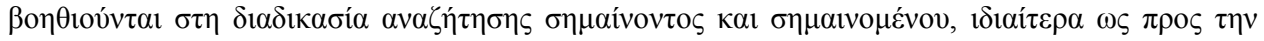

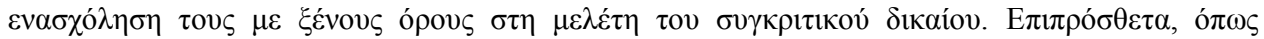

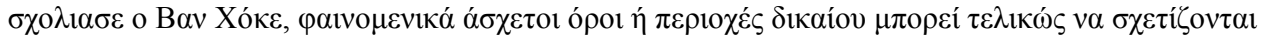

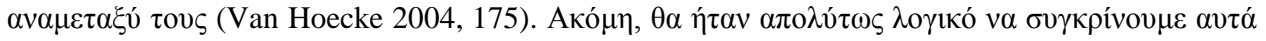

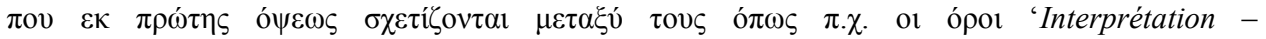

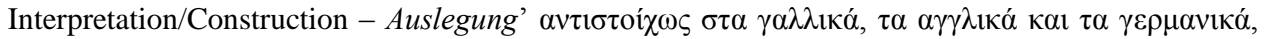

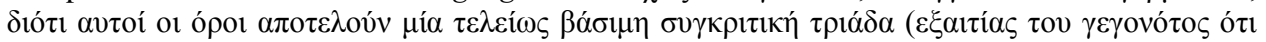

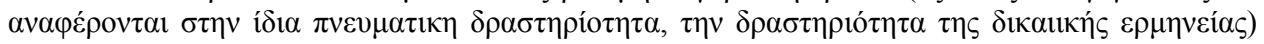

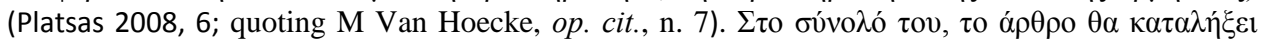

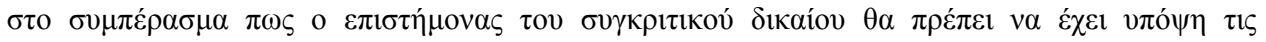

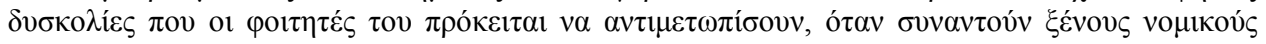

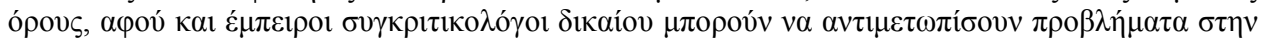

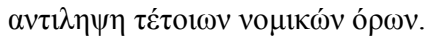

„Comparative lawyers are called on to do everything our domestically focussed colleagues do, but we also have to master an entire foreign legal system, in another language. In our domestic work we can be hedgehogs, but in our foreign law work we must be foxes. How many of us are to it?' (Merryman 1999, 31-32)

\section{Introduction}

Let us be honest: our law students do not seem to understand Latin and French terms used in legal English, let alone words that come from the terminology of a legal system which operates in a different language altogether. Typical foreign words used in every day legal English are such terms as ab initio (from the beginning), caveat emptor

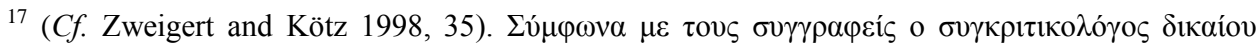

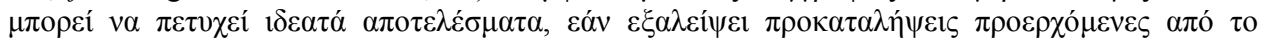

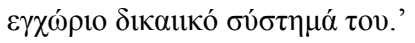




\section{Comparative Legilinguistics vol. 2/2010}

(let the buyer beware), modus operandi (a way of doing things), prima facie (on the face of things) and travaux préparatoires (preparatory works for the enactment of legislation) (Haigh 2009, 304-309). These words do not always make sense to the average law student.

To make matters more worrying, one cannot escape the fact that we lawyers are lost in translation, when it comes to actually 'translating' legal jargon in the language of the very legal system in which we operate. It would seem, therefore that English is one thing and legal English is quite another. The legal language in English speaking countries is difficult: the writing conventions are different to everyday language and a large number of peculiar words and phrases are used (Haigh 2009, 3). English looks misleadingly easy as a language and 'it may well be easy to gain quickly a modest - au pair - level of proficiency in English but in fact English, in particular written English, is rather a difficult language. This is all the more true when it comes to legal English' (Triebel 2009, 148). So too one identifies a number of legal terms of art (e.g. bailment, lien), legal jargon (e.g. corporate veil, examination-in-chief) and generally legal terms which have a very different meaning in every day language (e.g. consideration, tender, construction) (Haigh 2009, 4-5). For English lawyers the language used in law is what has been described by Lord Denning as a 'jungle'; he stated as follows in Davy v Leeds Corporation [1964]:

'I must say that rarely have I come across such a mass of obscurity, even in a statute. I cannot conceive how any ordinary person can be expected to understand it. So deep is the thicket that...both of the very experienced counsel lost their way. Each of them missed the last 20 words of subsection 8 of section 9 of the Act of 1959. So did the expert tribunal itself. I do not blame them for this. It might happen to anyone in this jungle'. ${ }^{18}$

Legal English is concerned by definition with coherence and precision (Crystal 2009, 374); maybe this is why the language which lawyers use is abstract. Maybe this is why lay people in the English speaking world will never be able to fully comprehend terminology. The realm of legal English is impenetrable (Crystal 2009, 374) and the few residents that are found within this realm are not always quite sure what the language of this realm always stands for. As a result, the task of making the same people (law students and lawyers) comprehend foreign legal terminology could be readily described as an onerous one.

\section{Comprehending Foreign Legal Terminology}

On the other hand, the comparative lawyer must be aware of a number of facts when it comes to foreign legal terminology so that his teaching task becomes easier (and by extension the learning task of his students becomes easier). First of all, one must be aware of the fact that there are certain conceptual differences between cultures due to language (Crystal 2007, 15). Second, the fact that a language may not use a word for a similar legal concept is not to say that the speakers of this language cannot grasp the concept (Crystal 2007, 15). However, even though language may not determine our mode

${ }^{18}$ [1964] 3 All ER 390, [1964] 1 WLR 1218, 16 P\&CR 244, 62 LGR 628, [1964] RVR 776, 128 JP 541. 


\section{Comparative Legilinguistics vol. 2/2010}

of thinking, it does influence our overall patterns of perception and recollection; this is what Crystal has forwarded as a weaker version of Sapir-Whorf's hypothesis (Crystal 2007, 15).

Close to this comes the fact that our comparative law students normally lack the conceptual background (Kischel 2009, 16-17) needed for the comprehension of foreign legal terminology. To add to this, one is warned that on certain occasions not even comparative lawyers themselves fully understand each other (let alone comparative law students comprehending foreign legal terminology). 'Language...proves to be one of the main obstacles [for the comparative lawyer]' (Brand 2009, 18). Also, the task of the comparative lawyer is particularly difficult when he deals with jurisdictions which do not belong to his/her wider legal circle of systems. Thus, it is one thing translating terms from western legal systems and quite another thing translating terms from a Muslim legal system to a western language (and vice versa) (Brand 2009, 21-22).

Language is an instrument (Anscombe 1968, 151e (\$569)) then: an instrument of cognition for us, comparative law teachers and our students alike. The former use this powerful instrument to make the latter penetrate foreign legal microcosms. Language conveys thoughts (Anscombe 1968, 102e (\$304), 139e (\$§501, 507)). We are reminded at this point that the largely accepted presumption on which this analysis acts is that the majority of legal concepts 'exist within the realm of language' (Brand 2009, 19). Furthermore, as Pound once said the science of comparative law is a 'science of words' (Wortwissenschaft) (Pound 1954, 7-16).

\section{Function}

Functionality is the governing principle of comparative law analysis (Glendon, Gordon and Osakwe 1994, 11; Platsas, 2008; Brand 2009, 31). A sort of obsession to comparative lawyers, the comparative lawyer must detect the 'functional equivalent' in the foreign jurisdiction in order for him/her to proceed with his/her analysis. Nonetheless, our students should not be lured by homonyms, as Kahn-Freund once warned us (KahnFreund 1965, 19). That is why Kischel has argued recently that 'linguistically equivalent legal notions will frequently have different contents in different jurisdictions' (Kischel $2009,7)$. Quite pessimistically though, he argued that 'the question in legal translation Is not which translation is right, but, much more modestly, which one is less wrong' (Kischel 2009, 7). As a result, one agrees with Kischel's former point but disagrees with his latter point. Such a disagreement with his latter point emanates from the fact that Academia generally serves realistic goals (as opposed to generally serving perfectionist goals). Thus, as Van Hoecke has argued:

'Strong epistemological pessimism has a perfectionist view on understanding. If you do not fully understand something, you do not understand anything. In practice this means that almost nobody can understand almost anything. A rather frustrating conclusion, especially for those whose professional life is centred around teaching and publishing' (Van Hoecke 2004, 171).

One must be able to make his/her students 'see'. How do we achieve this then? The litmus of functionality basically requires the comparatist to take a practical approach 


\section{Comparative Legilinguistics vol. 2/2010}

in the matter of his comparisons. It acts on the generally ${ }^{19}$ accepted hypothesis/presumption that legal systems around the world face similar legal problems (presumptio similitudinis) (Zweigert and Kötz 1998, 40).

Legal translation is quite similar to translating poetry. It is not a translating machinery which we require here; it is the art of translating which is needed. Meanings must go through; not words. As de Groot has recently argued, we can argue that a word is properly translated into another, if they both describe the same concept or idea (de Groot 2006, 424). In other words, we seek semasiological equivalence (de Groot 2006, 425426). Our aim is to make our students understand through the use of proper legal translations as opposed to understand through the use of literal translations (Sacco 1994, 475-490); (Wallow 2006, 11). How do we actually achieve that aim for our students, when we know that any given legal language presents problems of comprehension, even if that legal language operates in the confines of the language with which these students were raised?

Let us use the now refer to some classical examples in comparative law. Our first example deals with the terms 'Interprétation - Interpretation or Construction Auslegung'. It would be perfectly 'legitimate' on certain occasions for one to compare prima facie connected terms such as 'Interprétation - Interpretation or Construction Auslegung' respectively in French, English and German, since these terms are a perfectly valid comparative trio (all words basically refer to the same intellectual activity) (Platsas 2008, 6; quoting M Van Hoecke, op. cit., n. 3). Our second example is that of 'contrat Vertrag - contract', respectively in French, German and English law. These too make a perfectly valid comparative trio (Platsas 2008, 6; quoting M Van Hoecke, op. cit., n. 3). However, in our second example there are some caveats to be borne in mind. Accordingly, 'contrat' is offered two different significations in Articles 1101 and 1108 of the French Civil Code (Brand 2009, 30), whereas common lawyers perceive 'contract' as a much more confined term (Brand 2009, 30), something which is apparent by the fact that uniform instruments of law would take a wider approach in the matter. Moreover, the differences between Franco-German contract law and English contract law are stressed by the fact that in England we seek the so-called objective meeting of minds (Nicholas 1993), whereas in Continental Europe we seek the so-called subjective agreement of the wills (Nicholas 1993). In civilian contract law we will we will try to enquire into the true state of minds of the parties (Nicholas 1993), whilst in England we will ask what the dispassionate observer would have thought as to the existence of a contract (Nicholas 1993).

The situation in comparative law is echoed in the writings of international law. For instance, Bilder has dealt with the term of 'sovereignty' in the sphere of international law by referring to six (6) different meanings (Bilder 1994, 10-11) as quoted in (Beaulac $2004,2)$ of the same term, whilst Crawford argued that ' $[t]$ he term 'sovereignty' has a long and troubled history, and a variety of meanings.' (Crawford 1979, 26 as quoted in Beaulac, 2004, 2).

19 The presumption is generally accepted for, as Kötz himself characteristically states, 'the [praesumptio similitudinis] is a rebuttable presumption, and rebutted it must be when there is evidence for doing so.' See (Kötz 2003, 212) 


\section{Comparative Legilinguistics vol. 2/2010}

The function of words in law is most significant. As Beaulac has recently argued:

'Words are the origins of everything, of all aspects of human reality, which they both represent and create. [...] Indeed, words and expressions constitute irreducible neurones, which are necessary to communication within the shared consciousness of society'.

Law and language are inseparable (Grosswald Curran 1998, 43, 54). Therefore, if law's 'unique vehicle is [that of] language' (Beaudoin 2009, 143), one must be able to appreciate the value of detecting functional equivalents in two (or more) legal languages from different jurisdictions. At other times though a functional approach cannot suffice for the purposes of comparative analysis; it is context then which our comparative law teachers have to take into account for familiarising their students with foreign legal terms.

\section{Context}

Context affects comparative legal analysis to a significant degree. Law should normally be taught in context (Örücü 2004, 68). It has been said that '[r] eal world practice problems, not hypotheticals, are the best context' (Maharg 2007, 116). Our approach in comparative law follows the contextual pattern to a significant degree, because our students appreciate (and should appreciate) not only the law of foreign lands but also the surrounding legal atmosphere and the legal cultures of these lands (Maharg 2007, 116). More interestingly, our students evaluate their own legal culture by evaluating the legal cultures of others (Maharg 2007, 116).

Legal translation -one must admit- deals with the epiphenomenon of a legal reality; a reality which always has multicultural and multilingual ancestry, despite the reductionist approach which may be taken in the matter, i.e. that there is only one ancestry in a given legal culture (Stein 2009, 3). The typical example against this here is the use of legal Latinisms in many different languages around the world (Kischel 2009, 11-12). So too Roman law has been affected by Greek legal theory in that aequitas ( $\varepsilon л \iota \varepsilon i \kappa l \alpha)$ was a foreign term to original Roman law.

Legal culture results in defining legal language in judgments (Kischel 2009, 1314) and the very structuring of legal texts (Kischel 2009, 15) which differs immensely from jurisdiction to jurisdiction. The contextualist approach to legal translation operates at best- at an embryonic level. Brand states that the followers of this approach are still working on 'proto-methodological' level (Brand 2009, 32).

However, context is important in one's legal analysis. Hart for instance has argued that 'we cannot properly understand the law unless we understand the conceptual context in which it merges and develops' (Wacks 2009, 100). By way of analogy, the expectation is that legal translation of foreign terms in one's native language has to take into account two contexts (the legal/linguistic context where the translating terms comes from and the legal/linguistic context where the translating term is to be used). This has been referred to elsewhere as a relationship between a source culture and language on the one hand and a target culture and language on the other hand (Doczekalska 2009, 119 quoting Schäffner 1998, 84). Considerable parallels can be found here in relation to legal harmonisation projects and the underlying legal cultures which are to implement those unified legal standards: 'Our own legal cultures remain, for the time being, in certain 


\section{Comparative Legilinguistics vol. 2/2010}

areas, an important limiting factor to our harmonisation because [...] the application of the same rule may lead, despite all good intentions, to strikingly different results' (Lazareff 1999, 36 as quoted in Gotti 2009, 69). However, in our case, this approach presents a number of advantages in that it results in [acceptable] forms of differentiation between the source and the resulting text (Gotti 2009, 75). Accordingly, the comparative lawyer who 'translates' material from the legal microcosm of one language over to the legal microcosm of another should arrive at forms which are the 'outcome of negotiations between cultures and the norms and conventions involved' (Trosborg 1997, 146 as quoted in Gotti 2009, 75).

\section{Semainon and Semainomenon}

The semainon (signifier) and the semainomenon (signified) are key to our understanding of foreign legal terminology. These two concepts emanate from the subject of semantics, i.e. the subject which examines the meanings of language or more simply the meaning of words (Crystal 2007, 100). It is noted that semantics can have two different applications: application in the field of languages and application in the field of logic (Akmajian et al. 1990, 193). In this analysis we are interested in the application of semantics in the field of languages. Generally, words are mere conventions (Baskin and de Saussure 1960, 68). These words then are only one instance of a system of representative signs, the system here being that of language (Beaulac 2004, 19). Our thesis here is that comparative law teachers have to achieve for their students what linguists and legal translators achieve through their expertise, that being semantic equivalence (e.g. Doczekalska 2009, 116) (between source language and target language). Comparative law students find it difficult, however, to comprehend that one word in their language being written in the same way in another language has a different meaning altogether. They somehow seem to automatically 'register' this word as a linguistic (and hence legal) functional equivalent. They are lured by homonyms. ${ }^{20}$ For instance, 'jurisprudence' in French legal terminology refers, as a term, to case law, whereas the same term in English legal terminology refers to what we generically call legal theory. This is a case where our students 'believe [...] what one wants or believes' (Bollack, J. Sens Contre Sens as quoted by Legrand, 20002001, 1033). Or to put it, as Wittgenstein put it, since language can be perceived as a correlate of the world (Anscombe 1968, 44e (\$96)), then our English students correlate the term jurisprudence to their common law world experience. The fact that the term jurisprudence being interpreted the way it is interpreted and misinterpreted by our English students, when the same term is found in French legal terminology, verifies the point that language is agreed (Freeman 2008, 33-34, 1044 quoting Wittgenstein's approach on developing a conventional usage of words in particular types of activity) and it is not an agreement of opinions but rather an agreement in form of life (Anscombe $1968,88 \mathrm{e}(\$ 241))$. The reason behind this classic misunderstanding occurring amongst comparative law students is one that occurs by virtue of the fact that ' $[w]$ hen one resorts to a word, he or she must be deemed to refer to what it is usually and customarily

${ }^{20}$ For Kahn-Freund's classic warning (Kahn-Freund 1965, 19) in relation to homonyms and synonyms in comparative legal analyses see the abstract herein. 


\section{Comparative Legilinguistics vol. 2/2010}

accepted to represent in a highly complex system of (linguistic) signs within his or her society' (Beaulac 2004, 20). In other words, to refer back to Wittgenstein, there is interference of domestic linguistic convention (Anscombe 1968, 113e) vis-à-vis the semantics of foreign legal terminology here. If this point has some validity, then it is only a natural misunderstanding for English law students of comparative law to initially define French 'jurisprudence' as amounting to legal theory (as in their native English law). Equally, it is only a natural misunderstanding for French law students of comparative law to initially define English 'jurisprudence' as amounting to case law (as in their native French law). Words travelling from legal culture to legal culture do not result in the same semantic qualities (Legrand 2000-2001, 1038). They acquire a local meaning which makes them original (Legrand 2000-2001, 1039). Or, to put it in semantic language, the same signifier here (jurisprudence) results in two different signifieds (case law under French legal terminology and legal theory mutatis mutandis in English legal terminology). Equally, as David argued some time ago:

'To translate into English technical words used by lawyers in France, in Spain, or in Germany is in many cases an impossible task, and conversely there are no words in the languages of the continent to express the most elementary notions of English law. The words common law and equity are the best examples thereof; we have to keep the English words [...] because no words in French or in any other language are adequate to convey the meaning of these words, clearly linked as they are to the specific history of English law alone' (David 1980, 39).

Other misunderstandings arise when we have to translate expressions which should not otherwise present problems e.g. fair and regular trial as juicio justo $y$ imparcial (Spanish), procès juste et équitable (French) and díkaie kai adékastos díkē (Greek) (Gotti 2009, 57; translation into Greek made by the author of this article). Equally, reasonable in common law terminology does not necessarily and automatically translate into raisonnable (French) or vernüftig (German) (Gotti 2009, 57). Mortgage is not an automatic synonym to the German Hypothek, as the former signifies 'a transfer of an interest in land subject to an equity of redemption' (Triebel 2009, 150), whereas the latter is merely 'a legal [as opposed to an equitable] charge on the immovable property of another' (Triebel 2009, 150). The occurrence of this state of affairs is more frequent in comparative law works and the main consideration here is the lack of linguistic equivalence (and hence lack of functional equivalence) or to make things even more worrying the vagueness of the conceptual terms used (Gotti 2009, 57). Our main concern as comparative lawyers here is that, even if we were to accept that the above translations qualify as 'linguistic equivalents', should we automatically jump to the conclusion that these are 'functional equivalents' in law? Our illustration of the example in relation to the word jurisprudence points to the fact that our analysis should be precise.

What is the responsibility of the comparative law teacher then? How should he make sure that this divergence of meaning between the foreign semainon and the foreign semainomenon does not make his law students misunderstand? The author understands that there are three (3) methods/approaches in relation to closing the semantic gap: 


\section{Comparative Legilinguistics vol. 2/2010}

\section{- $\quad$ 'Familiarisation with the unfamiliar through the familiar' approach ${ }^{21}$}

- $\quad$ Periphrastic approach (through analysis and explanation) (See e.g. Anscombe 1968, 83e (§208))

\section{- $\quad$ Immersion approach (Grosswald Curran 1998, 44, 45, 57)}

In any case, our response should be one that is conducive to our old call in comparative law, i.e. we have to proceed with discipline and imagination, as Zweigert and Kötz have argued (albeit in a slightly different context) (Zweigert and Kötz 1998, 3637). Our voyage into foreign legal terminology is one which investigates terms and concepts found in other legal systems; this is an expression of academic interest (Anscombe 1968, 151e (\$570)), a common academic interest found amongst comparative law teachers and students alike. Our investigations into the foreign are driven by this interest. Maybe then we should proceed with discipline when it comes to finding the appropriate linguistic equivalents in other languages and we should proceed with our imagination when it comes to testing whether these linguistic equivalents present functional equivalents for our comparative purposes. As it has been rightly suggested, '[1]aw is not an exact science. [...] [I]t is entirely dependent on discourse [...]' (Beaudoin 2009, 137). Constructive imagination can then be used where the material which is taught to our students is 'linguistically approximated' (Šarčević 1997). Without doubt in relation to the former, we are in need of assistance of experienced legal translators, whereas legal translators should open a form of dialogue with comparative lawyers to verify whether linguistic equivalents and functional equivalents correspond. Therefore, Gotti's point, that translators working in this field 'should have two different types of competence: not only linguistic, but also legal' (Gotti 2009, 59), has considerable value. It is also true that the exercise of legal translation in comparative analyses leads 'far beyond - just - legal issues. It is (also) about identity, about entering a new world, first of all in terms of discourse, then (later) in terms of rights and commitments' (Lambert 2009, 91). This is an exercise of de-coding and re-coding (Grosswald Curran 2008, 679). Many of the problems that comparative lawyers face in the area, are also found in the operatives of the translating machinery of the European Union (EU) in that legal information has to be transferred in a number of other languages without loss of validity in the process of transfer from one language to another. In a sense, the work of the translator in an environment such as the $\mathrm{EU}^{22}$ does not differ much from that of the comparative law teacher in that both have to make sure that their translated material makes sense to their addressees. Effectively, we speak of a sort of discourse here; discourse which the comparative lawyer and the legal translator have to initiate with themselves in the first instance. It then becomes clear that the work of the comparative lawyer vis-à-vis his/her students is very reminiscent of what legal translators do; to draw an analogy one could perceive the comparative law exercise in relation to foreign terms as an 'act of communication' (Šarčević 1997, 50-86, 108-110, 227, 271, 276, 304), because the delivery of law (just as translation) is an act of communication.

\footnotetext{
${ }^{21}$ See e.g. Brand's point on conceptual comparisons (Brand 2009, 32); further see Zweigert and Kötz's point of terminological familiarisation on established concepts such as good faith, reasonableness and equity (Zweigert and Kötz 1998, 188-191).

${ }^{22}$ For a recent detailed account of the translation approach e.g. in the European Court of Justice see (McAuliffe 2009, 99-115)
} 


\section{Conclusion}

The analysis has shown that the comparative lawyer is to govern his approach under the headings of function, context and semantics. As has been shown, his/her teaching would greatly benefit by such an approach. In doing so there are three particular approaches: one approach is to introduce the unfamiliar via the familiar e.g. by attempting to make 'conceptual comparisons' (Brand 2009, 32). Another approach would be one to be periphrastic, i.e. analytical and explanatory. And certainly, one could make students think in foreign terms, after he/she has introduced his/her students to a foreign system, i.e. by operating under the immersion technique (Grosswald Curran 1998, 43). At times, we, comparative lawyers, should seek the assistance of experienced linguists (Brand 2009, 32), because -arguably- our approach would be less legalistic then. We should also seek the help of our colleagues, other comparative lawyers, who can act as correctives to the research which we undertake (Örücü 2004, 68). We should learn foreign languages and be trained in foreign legal terminology. We should listen to our students. We comparative lawyers are then rather like legal translators in a sense, who 'must be taught to keep the reader in mind when drafting their texts' (Beaudoin 2009, 144). So too, we should be reminded that we have to keep our students in mind, because they are not experts (nor have they to be). Above all, however, it is the re-alignment of our learning and teaching strategy that we should pursue here; effectively, we have to learn how to think so that we take into account the needs of our students.

\section{Bibliography}

\section{Primary Sources}

\section{Case Law}

Davy v Leeds Corporation [1964] 3 All ER 390, [1964] 1 WLR 1218, 16 P\&CR 244, 62 LGR 628, [1964] RVR 776, 128 JP 541.

\section{Secondary Sources}

\section{Books}

Akmajian, A., R.A. Demers, A.K. Farmer, and R.M. Harnish. 1990. An Introduction to Language and Communication. Cambridge: MIT Press.

Baskin, R. and de Saussure, F. 1960. Course in General Linguistics. London: Peter Owen.

Beaulac, S. 2004. The Power of Language in the Making of International Law. Leiden/Boston Martinus Nijhoff Publishers.

Crawford, J. 1979. The Creation of States in International Law. Oxford: Clarendon Press.

Crystal, D. 2007. The Cambridge Encyclopedia of Language. Cambridge: Cambridge University Press.

Crystal, D. 2009. The Cambridge Encyclopedia of the English Language. Cambridge: Cambridge University Press.

David, R. 1980. English and French Law. London: Stevens. 


\section{Comparative Legilinguistics vol. 2/2010}

Freeman, M.D.A. 2008. Lloyd's Introduction to Jurisprudence. London: Sweet \& Maxwell - Thomson Reuters.

Glendon, A.M., Gordon, M.W. and Osakwe, C. 1994. Comparative Legal Traditions, St. Paul, Minn.: West Publishing.

Kahn-Freund, O. 1965. Comparative Law as an Academic Subject. Oxford: Oxford Clarendon Press.

Haigh, R. 2009. Legal English. Abingdon: Routledge-Cavendish.

Maharg, P. 2007. Transforming Legal Education. Aldershot: Ashgate Publishing.

Merryman, J.H. 1999. The Loneliness of the Comparative Lawyer. The Hague: Kluwer.

Örücü, E. 2004. The Enigma of Comparative Law. Leiden/Boston: Martinus Nijhoff Publishers.

Šarčević, S. 1997. New Approach to Legal Translation. The Hague/London/Boston: Kluwer Law International.

Wacks, R. 2009. Understanding Jurisprudence: An Introduction to Legal Theory. New York: Oxford University Press.

Zweigert, K, and Kötz, H. 1998. An Introduction to Comparative Law. Oxford: Oxford University Press.

\section{Chapters or other parts of a book}

Beaudoin, L. 2009. Legal Translation in Canada: the Genius of Legal Language(s). In Translation Issues in Language and Law, eds. Olsen, F., Lorz, A., and Stein, D., 136-144. Basingstoke: Palgrave Macmillan.

Brand, O. 2009. Language as a Barrier to Comparative Law. In Translation Issues in Language and Law, eds. Olsen, F., Lorz, A., and Stein, D., 18-34. Basingstoke: Palgrave Macmillan.

de Groot, G.R. 2009. Legal Translation. In Elgar Encyclopedia of Comparative Law, ed. Smits, J., 423-433. Cheltenham: EE Publishing.

Doczekalska, A. 2009. Drafting or Translation - Production of Multilingual Legal Texts. In Translation Issues in Language and Law, eds. Olsen, F., Lorz, A., and Stein, D., 116-135. Basingstoke: Palgrave Macmillan.

Grosswald Curran, V. 2008. Comparative Law and Language. In The Oxford Handbook of Comparative Law, eds. Reimann, M., and Zimmermann R., 675-707. Oxford: Oxford University Press.

Kischel, U. 2009. Legal Cultures - Legal Languages. In Translation Issues in Language and Law, eds. Olsen, F., Lorz, A., and Stein, D., 7-17. Basingstoke: Palgrave Macmillan.

Kötz, H. 2003. The Trento Project and its Contribution to the Europeanization of Private Law. In The Common Core of European Private Law, eds. Bussani, M., and Mattei, U., 209-219. The Hague/London/New York: Kluwer Law International.

Lambert, J. 2009. The Status and Position of Legal Translation: a Chapter in the Discursive Construction of Societies. In Translation Issues in Language and Law, eds. Olsen, F., Lorz, A., and Stein, D., 76-95. Basingstoke: Palgrave Macmillan.

Lazareff, S. 1999. International Arbitration: towards a Common Procedural Approach. In Conflicting Legal Cultures in Commercial Arbitration: Old Issues and New 


\section{Comparative Legilinguistics vol. 2/2010}

Trends, eds. Frommel, S., and Rider, B., 31-38. The Hague: Kluwer Law International.

Gotti, M. 2009. Translation Issues in Language and Law. In Translation Issues in Language and Law, eds. Olsen, F., Lorz, A., and Stein, D., 55-75. Basingstoke: Palgrave Macmillan.

McAuliffe, K. 2009. Translation at the Court of Justice of the European Communities. In Translation Issues in Language and Law, eds. Olsen, F., Lorz, A., and Stein, D., 99-115. Basingstoke: Palgrave Macmillan.

Pound, R. 1954. Some Thoughts about Comparative Law. In Festscrift für Ernst Rabel ed. Dolle, H. Tübingen: Mohr.

Sacco, R. 1994. La traduzione giuridica. In Il linguaggio del diritto, eds. Scarpelli, U., and Di Lucia, P., 475-490. Milan: Edizioni Universitarie di Lettere, Economia e Diritto.

Schäffner, C. 1998. Parallel Texts in Translation. In L Bowker (ed), Unity or Diversity? Current Trends in Translation Studies, ed. Bowker, L., 83-90. Manchester: Saint Jerome Publishing.

Stein, D. 2009. Introduction: Forensic Translation - Practical Issues and their Theoretical Underpinnings. In Translation Issues in Language and Law, eds. Olsen, F., Lorz, A., and Stein, D., 1-4. Basingstoke: Palgrave Macmillan.

Triebel, V. 2009. Pitfalls of English as a Contract Language. In Translation Issues in Language and Law, eds. Olsen, F., Lorz, A., and Stein, D., 147-181. Basingstoke: Palgrave Macmillan.

Trosborg, A. 1997. Translating Hybrid Political Texts. In Text Typology and Translation, ed. Trosborg, A., 145-158. Amsterdam: Benjamins.

Van Hoecke, M. 2004. Deep Level Comparative Law. In Epistemology and Methodology of Comparative Law, ed. Van Hoecke, M., 165-196. Oxford and Portland Oregon: Hart Publishing.

Wallow, A. 2006. Herausforderung zu begrifflichen Reflexion: Recht und Sprache aus der Sicht des Rechtsvergleichers. In Law and Language - Recht und Sprache, eds. Lundmark, T., and Wallow, A., 3-13. Berlin/Hamburg/Münster: LIT.

\section{Translated works}

Anscombe, G.E.M., trans. 1968. Philosophical Investigations of Wittgenstein. Oxford, Basil Blackwell.

\section{Journal Articles}

Bilder, R.B. 1994. Perspectives on Sovereignty in the Current Context: An American Viewpoint. Canada-United States Law Journal 20: 9-17.

Grosswald Curran, V. 1998. Cultural Immersion, Difference and Categories in U.S. Comparative Law. American Journal of Comparative Law 46: 43-92.

Legrand, P. 2000-2001. The Return of the Repressed: Moving Comparative Studies Beyond Pleasure. Tulane Law Review 75: 1033-1052. 
Articles in online journals

Platsas, A.E. 2008. The Functional and the Dysfunctional in the Comparative Method of Law: Some Critical Remarks. 12(3) Electronic Journal of Comparative Law 6 (December), http://www.ejcl.org/123/art123-3.pdf (accessed June 3, 2009).

\section{Miscellaneous}

Nicholas, B. 1993. The United Kingdom and the Vienna Sales Convention: Another Case of Splendid Isolation?. Centre of Comparative and Foreign Law Studies, University of Rome I (March). http://servizi.iit.cnr.it/ crdcs/crdcs/frames9.htm (accessed June 3, 2009). 
